\title{
Social representations of history, wars and politics in Latin America, Europe and Africa
}

\author{
Elza TeChiO ${ }^{1}$, Magdalena BobOWIK ${ }^{2}$, Darío PÁeZ², Rosa

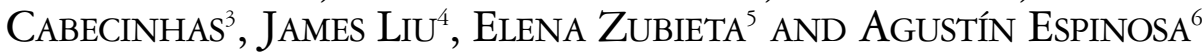 \\ ${ }^{1}$ Federal University of Sergipe, Brazil; ${ }^{2}$ University of the Basque Country, Spain; \\ ${ }^{3}$ University of Minho, Portugal; ${ }^{4}$ Victoria University of Wellington, New Zealand; \\ ${ }^{5}$ University of Buenos Aires, Argentina; ${ }^{6}$ Pontifical Catholic University of Peru, Peru
}

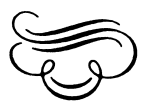

\begin{abstract}
This study analyzes how people perceive world bistory on three continents: Latin America, Europe and Africa. A total of 1179 university students form Argentina, Brazil, Peru, Portugal, Spain, Guinea-Bissau, and Cape Verde were asked to evaluate world events and leaders in terms of their valence and importance. The results demonstrated that social representations of history show a Euro/North American-centric, long-term positive evaluation, recency, and sociocentric bias. Euro/North American-centric events and leaders were found to be rated as more important and were more positively perceived in general. Distant political events, like French or American Revolution, were considered to be more positive than XX century similar events, which supports the long-term positive evaluation bias bypothesis. The bypothesis on recency bias was partially substantiated. Confirming the existence of such bias, World War II was rated as more important than the previous XX century wars and revolutions. Socio-centric bias also received partial support. African participants rated Mandela as a more important leader than other participants did. Latin Americans rated Che Guevara less positively, which suggests that some leaders are generally idealized icons, not based on group belongingness. However, results did not bring support to the centrality of war bypothesis. Wars were indeed negatively evaluated and World War II was rated as an important and negative event. Nevertheless, war-and politics-related events were not perceived as more important than the Industrial Revolution, suggesting that people appraise the importance of long-term socioeconomic factors of history when responding to close-ended quantitative measures (vs. open-ended salience measures). Results are discussed in the framework of social representations of history.
\end{abstract}

Keywords: Social representation, history events, leader world.

\section{Representaciones sociales de la historia, guerra y política en América Latina, Europa y África}

\section{Resumen}

El estudio analiza como las personas perciben la historia mundial en tres continentes: Latinoamérica, Europa y África. 1179 estudiantes universitarios de Argentina, Brasil, Perú, Portugal, España, Guinea-Bissau y Cabo Verde evaluaron una lista de eventos mundiales y líderes en lo que concierne a su valoración e importancia. Los resultados han mostrado que la representación social de la bistoria se caracteriza por un Euro centrismo, una evaluación positiva a largo plazo, y por sesgos socio-céntricos. Los eventos "Occidentales" (vinculados a Europa y Norteamérica) fueron evaluados como más importantes y percibidos más positivamente que los no-Occidentales. Eventos políticos distantes, como la Revolución Francesa o Americana, fueron evaluados más positivamente que eventos similares del siglo XX, apoyando la bipótesis de la evaluación positiva del pasado lejano. La hipótesis del sesgo de recencia o proximidad fue parcialmente confirmada, ya que la II Guerra Mundial fue evaluada como más importante que revoluciones o guerras anteriores al siglo XX. El sesgo socio-céntrico también recibe apoyo parcial. Los africanos consideraron a Mandela como un líder más importante comparado con los otros participantes. Los Latinos americanos evaluaron Che Guevara menos positivamente, lo que sugiere que ciertos líderes son generalmente íconos idealizados, y su valoración positiva no se basa en la proximidad o la pertenencia grupal. Sin embargo, los resultados no apoyaron la bipótesis de la centralidad de la guerra. Las guerras fueron efectivamente evaluadas negativamente y la II Guerra Mundial fue evaluado como la guerra más importante y como un evento muy negativo. No obstante, las guerras y eventos políticos relacionados con la violencia no fueron percibidos como más importantes que la Revolución industrial, sugiriendo que las personas valoran la importancia general de los factores bistóricos socioeconómicos cuando responden a medidas cuantitativas cerradas (vs. medidas abiertas). Los resultados se analizan desde el marco teórico de las representaciones sociales de la Historia

Palabras clave: Representación social, eventos históricos, líderes mundiales.

Author's Address: Elza Techio. Federal University of Sergipe. Núcleo de Pós-Graduação em Psicologia Social. Cidade Universitária Prof. Aloísio de Campos. Av. Marechal Rondon, S/N, Jardim Rosa Elze. 49.100.000, São Cristóvão. Brazil. Teléfono: (79) 2105-6784. E-mail: elzamt400@gmail.com 
The purpose of this study is to capture the sense of the views on the most important world historical events in a population of college students in three Latin American (Argentina, Brazil and Peru), two European (Portugal and Spain), and two African (Guinea-Bissau and Cape Verde) nations, sharing both distant (Latin American countries) or more recent colonial past (African countries, former Portuguese colonies), and a language as well (Portuguese and Spanish). We sought to learn how students without any formal training in history perceived the most important world historical events and leaders, and also to verify the valence ascribed by them to both using a newly developed quantitative survey. In other terms, the study explored shared images and beliefs about the relevant historical events or lay semantic memory of world history as an instance of collective memory.

Previous studies, using predominantly open-ended measures, have shown considerable cross-national consensus, with European history and Western cultural events being dominant, recent events considered more salient, war-related events and war-related leaders viewed as more prominent, and providing instances of sociocentrism at the national level (Glowsky, Ellermann, Kromeier \& Andorfer, 2008; Liu, et al., 2005; Pennebaker, Páez \& Deschamps, 2006). Basing on the findings of previous studies, we propose the existence of the following biases in the way people view history of the world:

a) Euro/North American-centric bias: the dominant social representations of world history are those related to the Western culture and history, especially to Europe and North America. Previous research has demonstrated a cross-cultural consensus suggesting the existence of collective memory or dominant and hegemonic shared beliefs about world history. As Liu et al. (2005) argue, "across cultures, social representations of history were overwhelmingly about politics and wars... the overall pattern was more Eurocentric than ethnocentric..." (p. 185). World events occur to be related to Europe (New World Discovery) or Europe and North America (world wars, Euro-Asian wars), or are simply European events, such as French Revolution or Lutheran reform (Pennebaker et al., 2006).

b) The centrality of warfare and politics (a "violence as the main factor of history narrative template" bias): revolutions and wars were dominant in the last millennium as the most important events, whereas science and technology, including the industrial revolution, were secondary in importance. In Liu et al.'s (2005) study, those events related to warfare were free-recalled above all other categories as being the most influential. A more recent study by Liu, et al. (2009) also showed that war-related events were most salient in freerecall measures of the most influential events in world history. Warfare and collective violence accounted for $48 \%$, and politics accounted for $27 \%$ of events nominated as important, whereas $45 \%$ of leaders named where known for their roles in wars and other collective violence events. Finally, $73 \%$ of leaders listed were politics-related. Even though wars produce only $2 \%$ of the XX century death toll (Layard, 2005), the participants should stress more the role of political violence in world history, given the fact that extreme and negative events like wars have higher impact.

c) Positive long-term evaluation: most of the long-term historical events listed by participants of previous studies (based on open-ended questions) reflected growth and positive change (Pennebaker et al., 2006). A positivistic long-term bias appears in the collective memory or social representations of history. Previous research has evidenced that people overemphasized mixed or positive long-term events, such as the New World Discovery, French and Industrial Revolutions, and overlooked less positive events, among them such important events as the Thirty Years War. Evaluation ratings also confirmed this long-term positivistic bias. For instance, the French Revolution was evaluated positively, suggesting that either people "forgot" about the terror, Napoleonic Wars and massacres, or that ample time had passed allowing individuals to reinterpret the events of that war. Studies that compare autobiographical memories 
of younger and elder people, or analyze within-subject comparisons between recent and more distant events, also confirm a nostalgic bias: increased age or longer periods of recalling are associated with more positive appraisal of events (Laurens, 2002). These and other studies suggest a tendency for people to remember a higher proportion of positive events than negative ones in the long term and to reinterpret negative events to be at least neutral or even positive (Taylor, 1991).

d) A recency bias: previous research (Liu et al., 2005) has also brought support for the existence of recency or "last years/century" bias; participants tended to view recent events as more historically significant than those which occurred long ago. In Pennebaker et al.'s (2006) study, three out of ten most important historical events of the last 1000 years mentioned by participants occurred in this century. Apparently, any event of historical significance has taken place after about 1500. Similarly, regarding the last 100 years, three out of ten events mentioned as important happened in the last decade. Finally, with reference to the past ten years, at least four most important events took place within a year prior to the participation in the study. In another study (Liu et al., 2009), the recency effects were found to be dominant in lay collective remembering, with events and leaders from the last 100 years accounting on average for $69 \%$ and $70 \%$ respectively of all named. In sum, in free-recall measures, people emphasize recent events because cohorts usually feel that "they are living during the most important and innovative period of world history", what in consequence demonstrates the existence of a "narcissistic" cohort bias.

One explanation of the recency bias is the phenomenon of collective memory, the oral transmission of vivid "first-hand" information about the event. Depth of genealogical memory (Candau, 2005) and of oral and vivid relatives' memories is three generations old. When asked about memories of traumatic and vivid events related to their relatives, people usually recollect events going only as far back as their grandparents (Pennebaker, Páez \& Rime, 1997). In the same vein, Wertsch (2002) found that the heroic II World War (WWII) narrative of the "Great Patriotic War" continues to play the role of a positive myth or social representation of the past in current Russia, and this is associated to the fact that WWII is still a part of autobiographical memory of people who share this experiences with their sons and grandsons, while this is not the case for WWI and the Russian Revolution. In other words, the recency bias occurs because collective memory is related to "fresh events" lived by the cohort, parents or grandparents. In the study by Liu et al. (2009) it was found that last 200 years accounted for $73 \%$ of events nominated across different cultures. The same study offered insight into a likely cause of recency effects, because many of the events nominated had not had time to be entered into official history textbooks, but rather were transmitted solely by mass media and word of mouth.

e) A socio-centric bias (Deschamps, Páez \& Pennebaker, 2001; Liu et al., 2005): the definition of historical importance was highly egocentric in previous studies. That is, each country tended to consider national-relevant historical events as more important than those which did not refer to the country. For instance, in Spain, participants rated the Spanish Civil War as the most important historical episode of the century while the U.S. participants listed the American Civil War as one of the most important events of the last millennium. History, by its very nature, is egocentric or socio-centric: "our" events are relevant for the world's history. However, in the case of Switzerland, with the partial exception of Lutheran reform, no national event was mentioned as relevant for the world's history (Pennebaker et al., 2006). This egocentric or socio-centric bias did not appear in some "minor" countries probably because low status groups are aware of their relative weakness in terms of historical capital; however, in others, like East Timor, the effect was exaggerated perhaps because of a lack of official education in world history and a heavy reliance on word of mouth. The results of more recent studies (Liu et al., 2009) showed somewhat less Eurocentrism among non-Western nations than in 
previous studies. Nonetheless, Western countries consistently reported very few events which occurred outside of their own region as contributing to the world's history. Similarly, non-Western countries exhibited ethnocentrism with respect to the events related to the creation of their own state.

This study aims at comparing previous results found with an open-response format to the results from the new World History Survey using a closed-response, quantitative format. It is expected that: a) participants would agree with the higher importance of Euro/North American-centric events and leaders in comparison to non-Euro/North American-centric ones (Euro/North American-centric bias); b) war- and politics-related events and leaders would be evaluated as more important compared to other events, such as science and technology inventions and discoveries (centrality of warfare and politics); c) participants would evaluate more positively the events which occurred before the XX century in comparison to those from the last century (positive long-term bias); $\mathrm{d}$ ) participants would consider as more historically significant the most recent historical events like WWII and Iraq War in comparison to respectively former ones (recency bias); e) regarding national events and leaders, a socio-centric bias would emerge with respect to events and leaders linked to national experiences, like colonization and Mandela being strongly related to African nations, or Discovery of America and Che Guevara, associated to Latin American history (socio-centric bias). Regarding the valence of both events and leaders (hypotheses a, b, d and e), predictions are similar in particular for socio-centric bias. For the other biases our expectations were not so clear, because people would probably consider extremely important events as very negative (e.g., World Wars) or very positive (e.g., French Revolution), cancelling by this way the valence effect.

\section{Method}

To examine the ideas set out above, a study was designed which enabled comparison of the importance and evaluation of a list of events and leaders based on the results from previous studies using open-response formats. The event inventory of the World History Survey included all leaders and events nominated in the top ten by two or more cultures, as reported by Liu et al. (2005; 2009). This produced a list of leaders and events which was then augmented by a few events chosen for specific theoretical purposes. The Foundation of the United Nations, Decolonization, and the Rise of Islamic Civilization were only nominated in 1 country, but were deemed sufficiently important to be included in the questionnaire. The Thirty Years War constituted a conflict between Catholics and Protestants which decimated Germany in the XVIIth century and which, together with the Invention of the Printing Press, was chosen to represent events of vast importance in previous eras, although did not seem to be salient in open-ended nominations. The Rise of the European Union, the Digital Age (computers, Internet) and Global Warming were chosen as events of signal importance to the future that may have been under-estimated. Finally, the Creation/Evolution of Humanity was also selected because the empirical survey so far disallowed events of greater than 1000 years antiquity, and we wanted to ascertain better the importance given to prehistory in overall ratings of world history. This event inventory is both comprehensive and content rich, and can be conceived as a valid cross-cultural instrument.

\section{Participants}

A total of 1179 university students from three continents participated in the study. The samples were comprised of students from: University of Buenos Aires, Argentina $(N=178 ; 47.8 \%$ female; age: $M=22.52, S D=4.71)$, University of Joinville and Tiradentes University, Brazil $(N=222 ; 73 \%$ female; age: $M=24.26, S D=7.79)$, Pontifical Catholic University of Peru $(N=83 ; 74.7 \%$ female, age: $M=20.27, S D=$ 
3.11), University of Minho, Portugal ( $N=208$; $68.8 \%$ female; age: $M=19.87, S D=$ 2.63), University of the Basque Country, Spain ( $N=183 ; 72 \%$ female; age: $M=25.06$, $\mathrm{SE}=8.73)$, University Amílcar Cabral and University of Colinas de Boe, GuineaBissau $(N=174 ; 24.7 \%$ female; age $M=26.55, S D=6.14)$, Jean Piaget University, Cape Verde $(N=131 ; 63.4 \%$ female; age $M=24.47, S D=5.71)$.

\section{Procedure}

Participants were asked to rate world events and leaders in terms of their positivitynegativity and importance. Following the procedure of Liu et al., (2009), the instructions were as follows:

"The following questions are about your ideas on history. They are part of a world-wide effort to construct an international inventory of opinion about what is important and unimportant in history, and how people see these events and persons. The questions should take only a few minutes of your time. Participation in this project is entirely voluntary and may be withdrawn at any stage of the questionnaire. Your answers are anonymous and only grouped results will be reported. Completing the questionnaire indicates your consent to participate in this project.

Below is a list of historical events. Please rate how positively or negatively you considerer each event (on a scale of 1 to 7 , with $1=$ extremely negative, $4=$ neutral, and $7=$ extremely positive). Please rate how important or unimportant you considerer each event (on a scale of 1 to 7 , with $1=$ not very important, 4 = somewhat important, and $7=$ of great importance)".

Both the list of historical events and the list of leaders included 40 items. For the purposes of this study the specific items were selected (by authors' agreement) to create four categories: Euro/North American-centric vs. Non-Euro/North American-centric Events and Euro/North American-centric vs. Non-Euro/North American-centric Leaders (Table I).

TABLE I

The list of Euro/North American-centric vs. Non-Euro/North American-centric Events and Euro/North American-centric vs. Non-Euro/North American-centric Leaders

\begin{tabular}{|c|c|c|c|}
\hline $\begin{array}{l}\text { Euro/North American- } \\
\text { centric Events }\end{array}$ & $\begin{array}{l}\text { Non-Euro/North American- } \\
\text { centric Events }\end{array}$ & $\begin{array}{l}\text { Euro/North American- } \\
\text { centric Leaders }\end{array}$ & $\begin{array}{l}\text { Non-Euro/North American- } \\
\text { centric Leaders }\end{array}$ \\
\hline $\begin{array}{l}\text { September 11th WTC } \\
\text { Renaissance } \\
\text { Thirty Years War } \\
\text { French Revolution } \\
\text { Industrial Revolution } \\
\text { World War I } \\
\text { Holocaust } \\
\text { Russian Revolution } \\
\text { Fall of Berlin Wall } \\
\text { Man on the Moon } \\
\text { Creation of EU } \\
\text { Digital Era }\end{array}$ & $\begin{array}{l}\text { Opium War } \\
\text { Sino-Japanese War } \\
\text { Cultural Revolution (China) } \\
\text { Vietnam War } \\
\text { Israel-Palestine Conflict } \\
\text { Islam Civilization } \\
\text { Partition of India-Pakistan } \\
\text { Asian Tsunami }\end{array}$ & $\begin{array}{l}\text { Stalin } \\
\text { Hitler } \\
\text { Napoleon } \\
\text { Charlemagne } \\
\text { Alexander the Great } \\
\text { George Washington } \\
\text { Abraham Lincoln } \\
\text { Franklin D. Roosvelt } \\
\text { George Bush Jr } \\
\text { Albert Einstein } \\
\text { Martin Luther } \\
\text { Pope John Paul II } \\
\text { Columbus } \\
\text { Isaac Newton } \\
\text { Karl Marx } \\
\text { Margaret Thatcher } \\
\text { Lenin } \\
\text { J.F. Kennedy } \\
\text { Thomas Edison } \\
\text { Princess Diana } \\
\text { Winston Churchill } \\
\text { Gorbachev } \\
\text { Bill Gates }\end{array}$ & $\begin{array}{l}\text { Mao } \\
\text { Ghengis Khan } \\
\text { Saladin } \\
\text { Qin Emperor } \\
\text { Osama Bin Laden } \\
\text { Mahatma Gandhi } \\
\text { Saddam Hussein } \\
\text { Buddha } \\
\text { Muhammed } \\
\text { Confucius } \\
\text { Deng Xiaoping } \\
\text { Sun Yatsen } \\
\text { Nelson Mandela } \\
\text { Mother Theresa } \\
\text { Che Guevara }\end{array}$ \\
\hline
\end{tabular}


Apart from the list with historical events and world leaders, the questionnaire included other variables taken into consideration in this study, such as: importance of religion $(1=$ not important at all, $4=$ very important $)$, political orientation $(1=$ liberal $/$ left-wing, 7 = conservative / right-wing $)$, national proud $(1=$ not proud at all, $4=$ very proud $)$, beliefs related to II World War and meaning of universal history ( 1 = strongly disagree, 7 =strongly agree).

\section{Results}

\section{Euro/North American-centric Bias - Importance and Valence of Historical Events and Leaders}

With the aim of contrasting the Euro/North American-centric bias hypothesis, a twoway Repeated Measures ANOVA was applied (2x7), with a 2-level within-subjects factor (Euro/North American-centric vs. Non- Euro/North American-centric), a 7-level between-subjects factor (country), and religiosity, political ideology and national proud variables introduced as covariates. Four models were contrasted for events and leaders' importance, as well as evaluations of both.

Evaluation of Events. As it is shown in table II, for the evaluation of events, the within-subject effect, the interaction effect, and the country (between-subject) effect were all significant. Within-subject effect confirms the following bias: Euro/North American-centric events were significantly more positively evaluated $(M=4.42)$ than Non-Euro/North American-centric ones $(M=3.10)$. Between-subject and interaction effects show between-nation variability, with African samples reporting the highest levels in their evaluation of Euro/North American-centric events (Guinea-Bissau: $M=$ 4.85; Cape Verde: $M=4.68$ ) and the Argentinean sample, in particular, being more neutral $(M=4.09)$. Non-Euro/North American-centric events were most positively evaluated by Guinea-Bissau $(M=3.17)$, and most negatively by Spain $(M=2.93)$, but these mean differences between countries were rather small. Additionally, paired samples t-test analysis performed for each nation proved that the within-subject differences were significant in each group considered as a separate unit of analysis (Spain: $t_{(150)}=24.67, p<.001 ;$ Brazil: $t_{(187)}=22.78, p<.001$; Argentina: $t_{(317)}=25.32$, $p<.001$; Peru: $t_{(68)}=24.67, p<.001$; Portugal: $t_{(162)}=28.54, p<.001$; Cape Verde: $t_{(49)}$ $=19.80, p<.001 ;$ Guinea-Bissau: $t_{(69)}=16.01, p<.001$ ), with comparable effect sizes when taking into consideration the sample size.

TABLE II

Between-country and within-country differences in the Evaluation and Importance of Euro/North American-centric vs. non-Euro/North American-centric Events and Leaders - Two-way Repeated Measures ANOVA results

\begin{tabular}{|c|c|c|c|c|c|c|c|c|c|}
\hline \multirow[b]{2}{*}{ Variable } & \multicolumn{3}{|c|}{ Between-subjects effects } & \multicolumn{3}{|c|}{ Within -subjects effects } & \multicolumn{3}{|c|}{ Interaction effects } \\
\hline & $F$ & $d f$ & $\begin{array}{l}\text { Partial } \\
\text { Eta } \\
\text { square }\end{array}$ & $F$ & $d f$ & $\begin{array}{c}\text { Partial } \\
\text { Eta } \\
\text { square }\end{array}$ & $F$ & $d f$ & $\begin{array}{c}\text { Partial } \\
\text { Eta } \\
\text { square }\end{array}$ \\
\hline $\begin{array}{l}\text { Events } \\
\text { (Evaluation) }\end{array}$ & $7.27 * *$ & 6 & .05 & $65.02 * *$ & 1 & .07 & $15.63 * *$ & 6 & .10 \\
\hline $\begin{array}{l}\text { Events } \\
\text { (Importance) }\end{array}$ & $11.28 * *$ & 6 & .08 & $97.47 * *$ & 1 & .11 & $16.31 * *$ & 6 & .11 \\
\hline $\begin{array}{l}\text { Leaders } \\
\text { (Evaluation) }\end{array}$ & $10.45 * *$ & 6 & .07 & $6.25 *$ & 1 & .01 & $15.50 * *$ & 6 & .11 \\
\hline $\begin{array}{l}\text { Leaders } \\
\text { (Importance) }\end{array}$ & $3.91 * *$ & 6 & .03 & $6.91 *$ & 1 & .01 & $3.52 *$ & 6 & .03 \\
\hline
\end{tabular}

Note. Results are partialed on ideology, religion importance and national proud. $* * p<.001 ; * p<.01$ 
Importance of Events. Regarding the importance of events, results obtained were also significant. In accord with hypothesis a, Euro/North American-centric events were generally rated as more important $(M=5.36)$ than Non-Euro/North American-centric ones $(M=4.25)$. Portugal reported the highest ratings of Euro/North Americancentric events $(M=5.79)$, whereas African nations, particularly Guinea-Bissau $(M=$ 4.79), reported the lowest ones. Non- Euro/North American-centric events, generally rated as less important, were found to be particularly devalued by African samples (Cape Verde: $M=3.97$, Guinea-Bissau: $M=3.09$ ). Again, when a dependent samples t-test was carried out for each national subgroup, the within-subject differences were significant (Spain: $t_{(146)}=12.29, p<.001$; Brazil: $t_{(176)}=16.49, p<.001$; Argentina: $t_{(313)}$ $=23.65, p<.001$; Peru: $t_{(64)}=12.41, p<.001$; Portugal: $t_{(166)}=23.60, p<.001$; Cape Verde: $t_{(32)}=10.27, p<.001$; Guinea-Bissau: $\left.t_{(36)}=19.53, p<.001\right)$.

Evaluation of Leaders. As far as leaders are concerned, results supported again the Euro/North American-centric bias hypothesis, given the fact that for evaluation ratings the within-subject effect, the interaction effect, and the country between-subject effect were all significant (Table II). Euro/North American-centric historical leaders were significantly more positively evaluated $(M=4.61)$, particularly by Portuguesespeaking nations (Brazil: $M=4.59$, Portugal: $M=4.71$, Cape Verde: $M=4.81$, and Guinea-Bissau: $M=5.07)$, whereas Non-Euro/North American-centric leaders were rated as neutral $(M=4.29)$ but still more negatively than Euro/North Americancentric ones, with Portugal being the nation who evaluated these events least positively $(M=4.16)$. In this case, the paired sample t-test was significant for Brazil $\left(t_{(168)}=8.60\right.$, $p<.001)$, Portugal: $\left.t_{(132)}=13.16, p<.001\right)$, Cape Verde $\left(t_{(37)}=4.76, p<.001\right)$, and Guinea-Bissau $\left(t_{(67)}=9.09, p<.001\right)$, while there were no significant differences for Spain, Argentina, and Peru.

Importance of Leaders. The fourth model with importance of leaders analyzed also substantiated hypothesis a. Euro/North American-centric historical leaders were rated as important $(M=5.14)$, with African nations showing lowest ratings (Guinea-Bissau: $M=4.79)$. Non-Euro/North American-centric leaders were evaluated neutrally regarding their importance $(M=4.66)$, however still as less important than Euro/North American-centric ones, particularly by Guinea $(M=4.04)$. In this instance, paired samples t-test analysis proved significant within-subject differences in each nation (Spain: $t_{(131)}=5.46, p<.001$; Brazil: $t_{(151)}=11.18, p<.001$; Argentina: $t_{(289)}$ $=17.94, p<.001$; Peru: $t_{(58)}=4.68, p<.001$; Portugal: $t_{(131)}=13.07, p<.001$; Cape Verde: $t_{(29)}=4.74, p<.001$; Guinea-Bissau: $\left.t_{(31)}=6.75, p<.001\right)$, although the effect sizes were relatively smaller in comparison to results regarding evaluation and importance of events.

All estimated standard means and standard errors for all countries in analysis are presented in table III.

\section{Long-term Positivity, Warfare Centrality and Recency Bias - Evaluation and Importance of Wars}

Dependent t-test pairs between relatively similar events from different centuries were conducted with the objective of testing the hypotheses on centrality of wars, longterm positivity and recency bias. With regard to long-term positivity and recency bias, we decided to focus on war-related events as by this way a more homogeneous set of historical events would be analyzed. The results are presented in table IV.

Centrality of wars. The results regarding the importance of wars served as a centrality of wars indicator. However, the warfare centrality hypothesis was not confirmed: warand politics-related events were not perceived as more important than socioeconomic trends. The Industrial Revolution was regarded as more important $(M=6.24)$ than revolutions (French Revolution: $M=5.58$; American War of Independence: $M=5.22$; 
TABLE III

Evaluation and Importance of Euro/North American-centric vs. non-Euro/North American-centric Events and Leaders by country - Estimated Marginal Means and Standard Errors

\begin{tabular}{lcccccccc}
\hline & $\begin{array}{c}\text { Events } \\
\text { (Evaluation) } \\
M \text { (SE) }\end{array}$ & $\begin{array}{c}\text { Events } \\
\text { (Importance) }\end{array}$ & $\begin{array}{c}\text { Leaders } \\
\text { (Evaluation) } \\
M \text { (SE) }\end{array}$ & $\begin{array}{c}\text { Leaders } \\
\text { (Importance) } \\
M \text { (SE) }\end{array}$ \\
\hline \multirow{2}{*}{ Overall } & 4.42 & 3.10 & 5.36 & 4.25 & 4.61 & 4.29 & 5.14 & 4.66 \\
& $(.03)$ & $(.03)$ & $(.04)$ & $(.05)$ & $(.02)$ & $(.02)$ & $(.04)$ & $(.04)$ \\
\hline Spain & 4.22 & 2.93 & 5.44 & 4.78 & 4.38 & 4.20 & 5.26 & 4.90 \\
& $(.06)$ & $(.06)$ & $(.07)$ & $(.09)$ & $(.05)$ & $(.05)$ & $(.07)$ & $(.07)$ \\
Brazil & 4.29 & 3.14 & 5.32 & 4.47 & 4.59 & 4.21 & 5.23 & 4.72 \\
& $(.04)$ & $(.05)$ & $(.05)$ & $(.07)$ & $(.04)$ & $(.04)$ & $(.06)$ & $(.06)$ \\
Argentina & 4.09 & 3.13 & 5.49 & 4.59 & 4.33 & 4.28 & 5.33 & 4.79 \\
& $(.03)$ & $(.04)$ & $(.04)$ & $(.05)$ & $(.03)$ & $(.03)$ & $(.04)$ & $(.05)$ \\
Peru & 4.26 & 3.16 & 5.42 & 4.32 & 4.37 & 4.29 & 5.07 & 4.81 \\
& $(.11)$ & $(.11)$ & $(.13)$ & $(.17)$ & $(.10)$ & $(.10)$ & $(.15)$ & $(.15)$ \\
Portugal & 4.53 & 3.12 & 5.79 & 4.53 & 4.71 & 4.16 & 5.31 & 4.78 \\
& $(.05)$ & $(.05)$ & $(.06)$ & $(.08)$ & $(.05)$ & $(.05)$ & $(.07)$ & $(.07)$ \\
Cape Verde & 4.68 & 3.08 & 5.26 & 3.97 & 4.81 & 4.37 & 4.96 & 4.57 \\
\multirow{3}{*}{ Guinea-Bissau } & $(.10)$ & $(.10)$ & $(.14)$ & $(.18)$ & $(.09)$ & $(.09)$ & $(.14)$ & $(.15)$ \\
& 4.85 & 3.17 & 4.79 & 3.09 & 5.07 & 4.50 & 4.79 & 4.04 \\
& $(.08)$ & $(.08)$ & $(.13)$ & $(.18)$ & $(.07)$ & $(.07)$ & $(.14)$ & $(.15)$ \\
\hline
\end{tabular}

Russian Revolution: $M=4.71)$, WWI $(M=5.68)$, WWII $(M=5.93)$, American Civil $\operatorname{War}(M=4.20)$, Thirty Years War $(M=4.18)$, Opium War $(M=3.84)$, Sino-Japanese $\operatorname{War}(M=3.90)$, Vietnam War $(M=4.67)$ and Iraq War $(M=5.06)$, with all $t_{(1110,1139)}$ $>5.56, p<.01$.

Long-term Positivity Bias. War- and politics-related events which occurred before the XX century (Thirty Years War: $M=3.03$; Opium War: $M=3.02$; American Civil War $M=3.30$ ) are generally regarded relatively less negatively or in a relatively positive light (American War of Independence /Revolutionary War: $M=$ 4.88; French Revolution: $M=5.2$ ), whereas war- and politics-related events which took place during the XX century are generally viewed as more neutral (Russian Revolution: $\mathrm{M}=3.99$ ) or more negative (WWI: $M=2.02$; WWII: $M=2.03$; Vietnam War: $M=2.06$; Israel-Palestine Conflict: $M=2.07$; Iraq War: $M=1.71$ ). Furthermore, politics-related events that include collective violence (America, French and Russian Revolutions) are generally better evaluated than wars. The dependent t-test analyses confirmed that the differences in evaluation of XX century events, such as WWII, and former events were statistically significant (Table IV). WWII was evaluated significantly more negatively than the Thirty Years War, American War of Independence, French Revolution, Opium War, American Civil War, Russian Revolution and Sino-Japanese War, whereas the differences between WWII and WWI were not significant. On the other hand, WWII was rated as more positive than one of the most recent wars, the Iraq War, whereas the differences with other recent events, such as Vietnam War and IsraelPalestine Conflict, were not significant. Hence, there was support for the hypothesis of long-term positivity bias.

Recency Bias. As far as the recency effect was concerned, WWII was rated as more important than the Thirty Years War, XVIII and XIX century wars and revolutions (Table IV). The current 2005 Iraq War was rated as more important $(M=5.06)$ than previous wars: the Thirty Years War $(M=4.19)$, Opium War $(M=3.86)$, American 
Civil War $(M=4.23)$, Russian Revolution $(M=4.71)$, Sino-Japanese War $(M=3.91)$, Vietnam War $(M=4.68)$, and Israel-Palestine Conflict $(M=4.77)$, being the results statistically significant with $t_{(1102,1130)}>5.50$. On the opposite, it was regarded to be less important than American War of Independence $(M=5.23)$, French Revolution $(\mathrm{M}=$ 5.58), and World Wars (I: $M=5.70$ and II: $M=5.94$ ), also reaching the significance level with $t_{(1137,1128)}<-2.65$. These results do not provide clear support for the recency bias hypothesis, as some former wars were considered more important that the Iraq war, one of the most recent ones.

TABLE IV

Evaluation and Importance of Wars - Means, Standard Deviations and t values

\begin{tabular}{lccccccc}
\hline \multirow{2}{*}{ War } & \multicolumn{3}{c}{ Evaluation } & \multicolumn{3}{c}{ Importance } \\
\cline { 2 - 8 } & $\boldsymbol{M}$ & $\boldsymbol{S D}$ & $\boldsymbol{t}$ & $\boldsymbol{M}$ & $\boldsymbol{S} \boldsymbol{D}$ & $\boldsymbol{t}$ \\
\hline Thirty Years War (1618-1648) & 3.03 & 1.43 & $-18,27^{*}$ & 4.19 & 1.48 & $33.42^{*}$ \\
American Independence (War) (1776) & 4.88 & 1.57 & $-43.11^{*}$ & 5.23 & 1.50 & $11.93^{*}$ \\
French Revolution (1789-1799) & 5.17 & 2.58 & $-35.65^{*}$ & 5.58 & 1.39 & $6.11^{*}$ \\
Opium War (XIX century) & 3.02 & 1.37 & $-18.08^{*}$ & 3.86 & 1.48 & $38.75^{*}$ \\
American Civil War (1861-1865) & 3.30 & 1.54 & $-21.91^{*}$ & 4.23 & 1.50 & $32.24^{*}$ \\
Russian Revolution (1917) & 3.99 & 1.51 & $-30.90^{*}$ & 4.71 & 1.53 & $23.30^{*}$ \\
I World War & 2.02 & 1.56 & .74 & 5.70 & 1.72 & $9.54^{*}$ \\
Sino-Japanese War (1930s) & 2.94 & 1.34 & $-17.28^{*}$ & 3.91 & 1.47 & $39.01^{*}$ \\
\hline II World War ** & 2.03 & 1.70 & & & 5.94 & 1.68 & \\
\hline Vietnam War & 2.06 & 1.34 &,- 81 & 4.68 & 1.74 & $25.10^{*}$ \\
Israel-Palestine Conflict & 2.07 & 1.32 & -1.06 & 4.77 & 1.78 & $23.46^{*}$ \\
Iraq War (2005) & 1.71 & 1.33 & $6.32^{*}$ & 5.06 & 1.87 & $17.22^{*}$ \\
\hline
\end{tabular}

$* p<.001$

** Dependent t-test was performed for pairs of comparison, where II World War was compared with the rest of events listed.

\section{Socio-centrism and the anchoring of representations of history}

To contrast the anchoring of history representations in the local context, a one-way ANOVA with African and Latin American history related events and leaders as dependent variables and country as the independent variable was performed.

A nations main effect was significant for both the evaluation and importance of all events and leaders included in the analysis, that is, among events: American Discovery, and Decolonization, and among leaders: Nelson Mandela and Che Guevara. Results, which are presented in table $\mathrm{V}$, confirm socio-centric hypothesis with respect to America Discovery, Decolonization and Mandela, but not regarding Che Guevara.

Discovery of America was generally positively evaluated $(M=5.36)$, however, there were significant between-countries differences. This event was rated significantly less positively in Spain $(M=4.96)$ and Argentina $(M=5.07)$ than in Brazil $(M=5.63)$, Portugal $(M=5.64)$, Cape Verde $(M=5.81)$ and Guinea $(M=5.36)$. There were also significant differences regarding the importance of this event, considered generally important $(M=6.01)$, with Argentina $(M=6.31)$ perceiving this event as more relevant than all non-American countries (Spain: $M=5.88$; Portugal: $M=5.62$; Cape Verde: $M=5.60$; Guinea $M=5.70)$, Brazil $(M=6.08)$ viewing it as more important than Portugal, and Peru $(M=6.30)$ ascribing it more importance than Portugal and Cape Verde.

As regards the Decolonization, the main effect was again significant both for evaluation and importance. Decolonization was rated as positive in overall $(M=5.4)$, 
but more positively in Portugal $(M=5.93)$ and African nations (Guinea, $M=6.05$; Cape Verde, $M=6.09)$ than in Spain $(M=5.19)$ and Latin American nations (Brazil, $M=5.37$, Argentina $M=5.4$, and Peru, $M=5.35$ ), with all differences significant (with exception of Peru vs. Portugal). This event was also considered generally important $(M=5.52)$, with significantly higher importance ascribed to it by Portugal $(M=5.93)$, Cape Verde $(M=6.09)$ and Guinea $(M=6.05)$ in comparison to Spain $(M$ $=5.19)$, Argentina $(M=5.40)$, Peru $(M=5.35)$, and Brazil $(M=5.37)$.

Finally, the country main effect was also significant for the evaluation and importance of the African leader Nelson Mandela and for the Latin American international icon Che Guevara. Mandela was generally positively rated $(M=5.65)$, although African nations reported significantly higher ratings (Guinea-Bissau, $M=$ 6.79; Cape Verde, $M=6.44)$ and Argentina $(M=5.09)$ the lower one in comparison to the rest of the countries. Guevara was evaluated positively $(M=5.21)$ but more negatively than Mandela. However, ratings were significantly lower in Latin American nations (Argentina, $M=4.7$; Peru, $M=4.79$; Brazil, $M=4.89$ ) than in European (mostly Spain) and African nations.

Mandela was reported to be an important leader $(M=5.69)$, with the ratings of importance, similarly to valence results, higher in African nations (Guinea-Bissau: $M$ = 6.51; Cape Verde, $M=6.68$ ) than in the rest of countries. Argentina considered Mandela significantly less important than most of the other countries (except Peru). Guevara's ratings of importance were higher $(M=5.59)$ and, similar to evaluation ratings, especially outside of Latin America - with the exception of Argentina, that reported a mean similar to the general one $(M=5.64)$. Concretely, Spain $(M=5.79)$ and Guinea $(\mathrm{M}=6.13)$ considered Guevara more important in comparison to Brazil $(M$ $=5.34)$ and Peru $(M=5.09)$.

TABLE V

Evaluation and Importance of African and Latin American bistory related Events and Leaders - ANOVA results (Means and $F$ values)

\begin{tabular}{ccccccccc}
\hline$M$ & $M$ & $M$ & $M$ & $M$ & $M$ & $M$ & \\
$(S D)$ & $(S D)$ & $(S D)$ & $(S D)$ & $(S D)$ & $(S D)$ & $(S D)$ & $F$ \\
Spain & Brazil & Argent. & Peru & Portugal & C. V. & Guinea & \\
\hline
\end{tabular}

\section{Evaluation}

\begin{tabular}{lcccccccc}
\hline Discovery of America & 4.96 & 5.63 & 5.08 & 5.04 & 5.64 & 5.81 & 5.36 & \multirow{2}{*}{7.58} \\
& $(1.65)$ & $(1.67)$ & $(1.97)$ & $(1.41)$ & $(1.30)$ & $(1.62)$ & $(1.69)$ & \\
Decolonization & 5.02 & 5.20 & 4.21 & 5.30 & 5.63 & 6.52 & 5.95 & \multirow{2}{*}{13.76} \\
& $(1.47)$ & $(1.52)$ & $(1.45)$ & $(1.21)$ & $(1.40)$ & $(1.16)$ & $(1.94)$ & \\
Nelson Mandela & 5.75 & 5.50 & 5.09 & 5.81 & 5.74 & 6.44 & 6.79 & 25.28 \\
& $(1.39)$ & $(1.48)$ & $(1.60)$ & $(1.30)$ & $(1.29)$ & $(1.31)$ & $(.73)$ & \\
Che Guevara & 5.70 & 4.89 & 4.72 & 4.79 & 5.28 & 5.88 & 6.54 & \multirow{2}{*}{24.72} \\
& $(1.17)$ & $(1.63)$ & $(1.90)$ & $(1.47)$ & $(1.55)$ & $(1.50)$ & $(.99)$ & \\
\hline
\end{tabular}

Importance

\begin{tabular}{lcccccccc}
\hline Discovery of America & 5.88 & 6.08 & 6.31 & 6.30 & 5.62 & 5.60 & 5.70 & \multirow{2}{*}{.70} \\
& $(1.28)$ & $(1.31)$ & $(1.17)$ & $(.99)$ & $(1.29)$ & $(1.38)$ & $(2.01)$ & \\
Decolonization & 5.19 & 5.37 & 5.40 & 5.35 & 5.93 & 6.09 & 6.05 & \multirow{2}{*}{} \\
& $(1.38)$ & $(1.40)$ & $(1.30)$ & $(1.18)$ & $(1.09)$ & $(1.39)$ & $(1.82)$ & 9.54 \\
Nelson Mandela & 5.76 & 5.67 & 5.24 & 5.67 & 5.90 & 6.68 & 6.51 & \\
& $(1.16)$ & $(1.38)$ & $(1.50)$ & $(1.14)$ & $(1.12)$ & $(.74)$ & $(1.26)$ & 17.94 \\
Che Guevara & 5.79 & 5.34 & 5.64 & 5.09 & 5.58 & 5.74 & 6.13 & \multirow{2}{*}{5.18} \\
& $(1.18)$ & $(1.52)$ & $(1.50)$ & $(1.42)$ & $(1.44)$ & $(1.26)$ & $(1.61)$ & \\
\hline
\end{tabular}




\section{Discussion}

The results of the study confirmed most of the hypotheses, demonstrating that quantitative evaluation and importance ratings of world history's collective memory is affected by a set of biases, such as Eurocentrism, positive long-term, recency and sociocentric bias, but is not characterized by the centrality of warfare and politics. Furthermore, this study might be considered as a new contribution to the results of previous studies with an open-response format, as they were confirmed with a closedresponse format questionnaire.

As far as the Euro/North American-centric bias hypothesis is concerned, Eurocentric representations of history were found to be dominant in the collective memory of world history for European and post-colonial African and Latin American countries. Euro/North American-centric events and leaders were generally rated as more important and more positive than non- Euro/North American-centric ones. These results are concordant with previous studies (Glowsky et al., 2008; Liu et al., 2005; Pennebaker et al., 2006). However, results demonstrated some crucial cultural differences. African nations devalued the importance of non-Euro/North Americancentric events more than Latin American and European ones. Although the effects were powerful in the post-colonial context investigated here, results could be attributed to item selection as the non-Euro/North American-centric events and leaders listed in the study were mainly related to Asia (China, India, etc.). Similar, though smaller, effects were found regarding Euro/North American-centric events. African nations, in this case Cape Verde and Guinea-Bissau, generally devalued the events included in this study, which are clearly linked to European, American or Asian history (the list practically did not include crucial events from the history of Africa). Thus, such responses of Africans are not surprising at all.

One explanation might be that the nucleuses of representations of Capeverdian and Guinean history, their charters, seem not to include most of Eurocentric events and leaders as relevant. On the other hand, ongoing history, that is, the current situation in both countries speaks for itself: the recent assassination of Guinea-Bissau president Joao Bernado Vieira, droughts which made Cape Verde dependent on food imports and prompted heavy migration flows are important national experiences which can push world events into the shadows. In other words, the results confirm that people exhibit a tendency to anchor their representations of history in recent events. In this case, the findings of the study might be considered a confirmation of the idea proposed by Liu and Hilton (2005) that not only the past weighs on the present but also the present weighs on the past, in accord with the classical hypothesis of collective memory that current concerns and attitudes influence social remembering (Pennebaker et al., 1997). These results can be also seen as in line with Liu et al.'s (2009) study, in which East Timor showed a rather ethnocentric pattern of results, where almost all events nominated in the Top 10 of World History "could either be related to a narrative about the emergence of East Timor as a sovereign state, or was very recent and could be related to worldwide struggles against forces associated with Islamic fundamentalism".

Recent studies conducted in Cape Verde using an open-response format (Cabecinhas \& Évora, 2008) revealed a Euro/North-American bias tempered by some degree of ethnocentrism.

As it was already mentioned, the results obtained did not substantiate the hypothesis on the centrality of wars and politics in social representations of history. War- and politics-related events were not perceived as more important than socioeconomic trends when evaluated using a closed-ended, quantitative format compared to an open-ended, free-response format. The Industrial Revolution was rated as more important than war- and politics-related revolutions and World Wars. Such findings might have been affected by the questionnaire format: open-response format 
involves a cognitive processing based on recollection, while closed-response format requires recognition processes to be applied. As far as recollecting events considered by each participant as most important in world history, as it was in previous studies (Liu et al., 2005; Liu et al., 2009), can be seen as a process that takes a form of a mixture of emotional induction and cognitive decision-making, then recognizing events listed as important (or not) involves less personal implication and depends less on each event's vividness and more on its familiarity and stock knowledge. Thus, importance and evaluation appraisals based on the recovery of semantic information might result in less extreme evaluations for wars. Of course, it does not directly explain why the Industrial Revolution was considered as more important than most of the warfare-related events, but it does explain why in an open-response format people mention war- and politicsrelated events as a cluster and such events as the Industrial Revolution are not as easily accessible. When recollecting events, one refers to the information provided in mass media or textbooks, which are to a large extent dominated by violence-related events and which, in case of mass media, live off them. However, once other events - which might not be as easily recollected as war - are listed, they are recognized as crucial for world history. We can conclude that free recall or spontaneous representations of history reproduce the ideology of violence and leaders as the most important factor of history, while general representations of history rather include the importance of long-term socio-economic processes. Moreover, in the same samples (data not shown in this paper) the agreement with statements that describe the content of history as being related to wars and politics was lower $(M=3.66)$ than the agreement with the idea of history as being related to economic and technological development (4.7 in a scale from $1=$ totally disagree to $7=$ totally agree).

On the other hand, the results clearly show a trend in which more recent historical events are view less positively than those events which took place further back in history. The war- and politics-related events which occurred before the XX century were generally regarded in a relatively positive light, whereas war- and politics-related events which happened during the XX century were viewed as more negative. This pattern is congruent with the fact that in the same samples (data not shown in this paper) a progressive view of the history is dominant: the agreement with statements that describe the content of history as related to wars and politics (see above) and suffering was lower $(M=3.5)$ than the agreement with the idea of history as related to social and political progress ( 4.5 in a scale from $1=$ totally disagree to $7=$ totally agree). However, an important caveat is that wars in general were very negatively evaluated, including "old" wars like the Thirty Years War. Furthermore, the most recent events, such as the Iraq War, are seen as even more and extremely negative in comparison to World War II. Results concerning Israel-Palestine Conflict do not confirm the positive long-term effect; however, it should be taken into consideration that this conflict was not as "hot" in the moment of data recollection as it is in mass media in recent months. These results are consistent with those obtained in Liu et al.'s (2009) study, where the most recent events and leaders, such as 9-11, Iraq War, and G. Bush Jr, were seen as more negative than World War II and Hitler. This profile is congruent with the wellknown positive-negative asymmetry effect: negative events are easily detected and influence our perception, evaluation and judgments more, as well as being better retained at short-term. This tendency is supposed to be adaptive because negative events are more informative and require more rapid reactions than positive ones. In the same vein, mass media and journalists focus more on negative news (Bar-Tal, Halperin $\&$ de Rivera, 2007). Hence, this might be an explanation for the recency-based negative bias.

However, long-term positive bias was clear, especially with respect to politicsrelated events like the Revolutions, which are, in general, more positively evaluated than warfare-related ones, like the American Civil War. Analogically, relatively similar 
events, like the French Revolution (that provoked also a European war and internal massacres as the so called genocide of La Vendée) and the World Wars, showed opposite profiles. Even though both conflicts resulted in thousands of deaths, the French Revolution was evaluated relatively positively. Specifically, when evaluations of the positivity of the French Revolution were compared with more recent historical events, the French Revolution was rated as being significantly more positive than World War I and II. Thus, it would appear as though people "forgot" about the widespread terror, the Napoleonic Wars and massacres, and emphasized more the positive ideals (e.g., freedom, equality, and fraternity) associated with the French Revolution. This positive reconstruction was manifest even in the case of socio-economic important events. For instance, the Industrial Revolution was evaluated positively (5.6 on a seven point scale), indicating that people tend to "forget" social problems, exploitation of labor and decrease in life expectancy brought about by the initial stages of the industrial revolution. This positivity long-term bias was evident in the well-known slogan of Communist Parties (and currently ironic comment): "in the long-term, the global balance of socialism is positive".

This tendency is congruent with two facts: the effect of perspective and the asymmetry of positive information in long-term memory and cognition. First, taking a more distant and long-term perspective, either experimentally induced or because the person is older, provokes a process of positive reappraisal and reconstruction of the past. In fact, it is the long-term perspective that facilitates a positive reappraisal, because long-term future is usually better evaluated than the near one (Laurens, 2002). Second, positive information is better analyzed and retained in the long term, because it is less threatening and reinforces well-being, but also because positive information is simpler and easier to learn (Unkelbach, Fiedler, Bayer, Stegmüller \& Danner, 2008). Extant studies show a positive bias in autobiographical memory, linguistics, and communication. For instance, people remember positive events (related to pride) with more details than negative events (related to shame) for events that involve selfevaluations. In addition, this bias was stronger for people high in self-esteem (D'Argembeau \& van der Linden, 2008).

What is more, people remember more positive autobiographical emotions and events than unpleasant ones. This is due not only to the fact that often positive life events outnumber negative life events, but also because the intensity of affect of these positive events in memory fades slowly. This differential fading of affect gives persons a heightened sense of positivity when remembering their life events (Walker, Skrowronski \& Thompson, 2003). Positive words are used with higher frequency than negative ones (at least in Western societies), and positive words are more primary and stand for the whole concept or dimension (e.g., "happy" is more used, more simple and stands for the whole dimension of hedonic valence, while "unhappy" is secondary, more complex and stands only for a part of the dimension (Matlin \& Stang, 1978). Usually, negative information is minimized or reconstructed in interpersonal communication (Taylor, 1991). These psychological tendencies are usually stronger in rituals, monuments and other cultural products: what is negative is rarely commemorated (Pennebaker et al., 1997). We can conclude that biases affecting the personal and social memory are psychological mechanisms used to maintain a positive individual and collective self-image, and explain the long-term positivity bias in social representations of history in the societies we investigated. Future research is necessary to see whether these effects are replicated in East Asian societies, where the existence of such positivity biases is the topic of controversy: some authors propose that self-enhancement and positivity bias are not universal (e.g., Heine et al., 2001; Markus \& Kitayama, 1991), while others based on meta-analytical studies which report findings favoring the universality of self-enhancement (Sedikides, Gaertner \& Vevea, 2005) and positivity 
bias in attribution - including among Asian collectivist (Mezulis, Abramson, Hyde \& Hankin, 2004).

The results partially confirm the recency effect. WWII was rated as more important than Thirty Years War, XVIII and XIX wars and revolutions. The current 2005 Iraq War was rated as more important than previous American Civil War and Russian Revolution - but not than World Wars or French Revolution, indicating that strongly Eurocentric but less recent events might be evaluated as more important than those ongoing, "fresh" ones in spite of time distance.

With regard to the last hypothesis on the socio-centric bias, the results give support to the idea that people exhibit ethnocentrism in their view of universal history and include their country-related historical events and leaders in world history. Thus, the Discovery of America was viewed as positive in general, as an instance of positive reconstruction. This implies the tendency of people (especially in dominant groups) to forget the high death toll related to European settlement, wars of conquest, exposure to new illnesses, and the horrors of colonization and slavery. For instance, population of Mexico decreased from around 20 million in 1500 to two millions in 1650, mainly due to epidemics that conquerors brought with them (Ferro, 1994). However, Portuguesespeaking nations reported a more positive evaluation of this historical event, suggesting that people share the white legend of positive Lusophone exploration activities. Sa and de Oliveira (2002) also found that the most frequent and first mentioned ideas associated to the Discovery of Brazil were positive both in Portugal and Brazil, suggesting that the positive social representation of the Discovery of America is dominant in both cultures. Also confirming the socio-centric hypothesis, the importance of the Discovery of America was higher in Latin American nations than in European and African ones - even if the event was rated as important (above 5) in all nations.

Finally, the End of Colonization was seen as positive in general and, consistently with previous results, as more positive in Portugal and in African nations. Also the importance of Decolonization was higher in these nations. The more extreme ratings of valence and importance could be explained by the fact that these countries were involved in more recent decolonization, confirming again the hypothesis that people anchor their representations of history in current experiences and interests. On the other hand, although not as positive as in Portuguese-speaking nations, Decolonization was slightly better evaluated in Peru than in Argentina and Brazil. Such finding could be explained by the indigenous character of the country, and it is probable that the difference would be even intensified if the sample was not restricted mostly to the welleducated middle class and mixed race people, typical of urban university educated samples in Latin America.

In sum, the general profile of results regarding some specific historical events suggests the existence of a shared culture and view of the colonial past in Portuguesespeaking nations: more critical regarding colonization but more positive in relation to discoveries.

With respect to leaders, as far as Nelson Mandela was concerned, the socio-centric hypothesis was supported: he was evaluated positively and as an important leader, with African nations evaluating him better that the rest of the countries. However, the data did not support socio-centrism for the Latin American icon Che Guevara: ratings of valence and importance were lower in Latin American nations than in European and African nations, giving support to the idea that the image of Che Guevara is rather a function of the tendencies dominating among today's youth. Che Guevara is generally considered to be a worldwide symbol of revolution and fight against social injustice and class struggle, with his dream of promoting a "moral" consciousness against "material" drives, in sum, a quintessential icon of leftist-inspired movements rather than an ethnocentric Latin American historical leader. What is more, for example in the case of 
Argentina and Peru, Che Guevara's image can be considered affected by collective violence episodes. In fact, both the Argentinean ERP guerrilla (1969-1976) and Peruvian "Tupac Amaru” Revolutionary Movement (MRTA, active in the eighties and nineties of the XX century) were inspired by Guevara's ideology. Direct experience with collective violence and suffering, as well as with the political and military failure of these urban guerillas against regular armies probably eroded the idealistic image of the "Heroic Guerrillero" that prevails in more distant nations. As a general finding, positive social representations of collective violence are more strongly endorsed by people not directly involved, who can thus maintain a positive view of armed struggle, while not having to live directly with the extremely negative experience of actual collective violence (Páez, et al., 2008). Another complementary explanation is the political position of samples. Peru and Argentina report a more centre-left (mean around 4 in a $1=$ Leftist to $10=$ Rightist) orientation than the other nations (with means around 3.1 - 3.8). In fact, the correlation between political position and Guevara's evaluation is $r_{(N=1128)}=.30$, confirming that, as a political icon, the "Heroic Guerrillero" belongs to the collective memory of the left.

\section{Conclusion}

In conclusion, the results of this study confirmed that people across the cultures in post-colonial settings perceive world history in a rather similar manner and are prone to some cognitive distortions in their evaluation of the importance and valence of historical events and leaders. Euro/North-American-centric events and leaders were found to be rated as more important and more positively evaluated. African nations devalued more the importance of non-Euro/North-American-centric events than Latin American and European ones. The non-Euro/North-American-centric events and leaders listed in the study were mainly related to Asia and the lack of African events helps to explain in part such findings. However, this also means that non-Europeans, to a certain extent, share Euro/North-American-centric representations of history. Social representations of history also show a recency effect, confirming the central role of World War II, which was rated as more important than previous XX century wars and revolutions. However, the current 2005 Iraq War was rated as less important than World Wars or French Revolution, suggesting that some distant events appear as historical markers. At odds with previous studies, war- and politics-related events were not perceived as more important than the Industrial Revolution. We concluded that, even if wars are more vivid in free recall, semantic knowledge reinforces a materialistic and economic view of the history, that was evident in the agreement of participants with history as being related to socio-economic development more than history as being a story of wars and conflicts. Socio-centric bias was partially confirmed and explained why African participants rated Mandela as an extremely important leader. This bias did not explain why Latin Americans rated Che Guevara less positively, and suggests that some leaders are generally idealized icons of revolt and social change, not based on proximity, familiarity or national belongingness.

\section{References}

Bar-Tal, D., HalPerin, E., \& De Rivera, J. (2007). Collective Emotions in Conflict Situations. Journal of Social Issues, 63, 441-459.

CANDAU, J. (2005). Anthropologie de la Mémoire. Paris: Armand Colin.

CABECINHAS, R. \& ÉvorA, S. L. (2008). Visões do Mundo e da Nação: jovens cabo-verdianos face à história. In M. Martins \& M. Pinto (Org.), Comunicação e Cidadania (pp. 2685-2706). Braga: Centro de Estudos de Comunicação e Sociedade.

Deschamps, J. C., PÁez, D., \& Pennebaker, J. (2001). Mémoire Collective des évenements socio-politiques et culturels: répresentation sociale du passé à la fin du millenium. Psychologie et Société, 2, 26-35.

D'Argembeau, A. \& VAN Der Linden, N. (2008). Remembering pride and shame: self-enhancement and the phenomenology of autobiographical memory. Memory, 16, 538-546.

Ferro, M. (1994). Histoire des colonisations. Paris: Eds. Du Seuil. 
Glowsky, D., Ellermann, H., Kromeier, K., \& Andorfer, V. (2008). A Global Collective Memory? Results from a Quantitative Pilot Study. Comparativ, 2, 99-115.

Heine, S. J., Kitayama, S., Lehman, D. R., Takata, T., Ide, E., Leung, C., \& Matsumoto, D. (2001). Divergent consequences of succes and failures in Japan and North-America. Journal of Personality and Social Psychology, 81, 599-615.

LAURENS, S. (2002). La nostalgie dans l'elaboration des souvenirs. In S. Laurens \& N. Roussiau (Eds.), La mémoire Sociale (pp. 259-268). Rennes: Presses Universitaires de Rennes.

LAYARD, R. (2005). La Felicidad. Madrid: Taurus.

Liu, J. H., Goldstein-Hawes, R., Hilton, D. J., Huang, L. L., Gastardo-Conaco, C., Dresler-Hawke, E., Pittolo, F., Hong, Y. Y., Ward, C.; Abraham, S., Kashima, Y., Kashima, E., Ohashi, M., Yuki, M. \& Hidaka, Y. (2005). Social representations of events and people in world history across twelve cultures. Journal of Cross Cultural Psychology, 36 (2), 171-191.

Liu, J. H., \& Hilton, D. (2005). How the past weighs on the present: Social representations of history and their role in identity politics. British Journal of Social Psychology, 44, 1-21.

Liu, J. H., PÁez, D., Slawuta, P., Cabesinhas, R., Techio, E., KoKdemir, D., Sen, R., Vincze, O., Muluk, H., Wang, F., \& Zlobina A. (2009). Representing World History in the $21^{\text {st }}$ Century: the Impact of 9-11, the Iraq War, and the Nation-State on Dynamics of Collective Remembering. Journal of Cross-Cultural Psychology, 40 (4), 667-692.

Matlin, M. W. \& Stang, D. J. (1978). The Pollyana Principle. Cambridge, MA: Schnekman.

Markus, H., \& Kitayama, S. (1991). Culture and self: Implications for cognition, emotion and motivation. Psychological Review, 98, 224-253.

MeZULIS, A. H., ABramson, L. Y., Hyde, J. S. \& HANKIN, B. L. (2004). Is there a universal positivity bias in attributions? A meta-analytical review of individual, developmental, and cultural differences in the self-serving attributional bias. Psychological Bulletin, 130, 711-747.

PÁez, D., Liu, J., Techio, E., SlawUta, P., Zlobina, A., \& Cabecinhas, R. (2008). Remembering World War II and Willingness to Fight: Sociocultural Factors in the Social Representation of Historical Warfare across 22 Societies. Journal of Cross-Cultural Psychology, 39 (4), 373-401.

PeNNEBAKER, J., PÁEZ, D. \& DESCHAMPS, J.-C. (2006). The social psychology of history: Defining the most important events of the last 10, 100 \& 1000 years. Psicología Politica, 32, 15-32.

Pennebaker, J., PÁez, D. \& Rime, B. (1997). Collective Memory of Political Events. Mahwah, NJ: Lawrence Erlbaum.

SA, C. P. \& DE OliveirA, D. C. (2002). Sur la mémoire sociale de la découverte du Brésil. In S. Laurens \& N. Roussiau (Eds.), La mémoire sociale: Identités et représentations sociales (pp. 107-118). Rennes: Presses Universitaires de Rennes.

Sedikides, C., Gaertner, L., \& VeveA, J. L. (2005). Pancultural Self-enhancement reloaded: a meta-analytic reply to Heine. Journal of Personality and Social Psychology, 89, 539-551.

TAY̌LR, S. (1991). Asymmetrical effects of Positive and Negative Events: the Mobilization-minimization hypothesis. Psychological Bulletin, 110, 67-85.

Un Uelbach, C., FIEDler, K., BAYER, M., Stegmüller, M., \& DANner, D. (2008). Why Positive Information is Processed Faster: the Density Hypothesis. Journal of Personality and Social Psychology, 95 (1), 36-49.

Walker, R. W., Skrowronski, J.J., \& Thompson, C. P. (2003). Life is Pleasant - and Memory Helps to Keep it that Way. Review of General Psychology, 2, 203-210.

WerTSCH, J. V. (2002). Voices of collective remembering. Cambridge: Cambridge University Press. 